\title{
Knowledge and Acceptability of Cervical Cancer Screening among Adult Women Visiting in Gynecological OPD
}

\author{
Bishnu Kumari Shrestha, ${ }^{1}$ Devi Kumari Sapkota, ${ }^{1}$ Mathura Sapkota ${ }^{1}$ \\ ${ }^{1}$ Bharatpur Nursing College, Bharatpur, Chitwan, Nepal.
}

\begin{abstract}
Background: Cervical cancer is the most common form of cancer among women developing countries. Pap smear is a very significant screening test for reduction of incidence and mortality from cervical cancer. The pap smear test detect precancerous cell change on the cervix that might become cervical cancer if they are not treated appropriately. The objective of this research is to find out the knowledge and acceptability of cervical cancer screening among adult women. Methods: A cross-sectional research design was conducted among 425 gynecological patients of Bharatpur hospital OPD of 30 to59 years of age. Semi structured questionnaire was used in data collection. Results: The mean age of participants was $40.07 \pm 7.9$ years. Majority of the respondents, 247 (58.1\%) had good knowledge in cervical cancer screening and $282(66.4 \%)$ of the respondent accepted Pap smear test. Mean knowledge score on sign and symptom of cervical cancer was $62.1 \%$, in risk factor was $72.8 \%$ and in preventive measure was $82 \%$. Study showed the association between respondents knowledge of cervical cancer screening with educational status $(p=0.04)$, religion $(p=0.01)$ at 0.05 level of significance. There was association between respondents' level of knowledge and acceptability of cervical cancer screening $(\mathrm{p}=0.02)$ at 0.05 level of significance. Conclusions: Majority of participant had never screened for cervical cancer, information get from health care provider was poor and acceptability rate is low. So the study recommends that health care provider should provide the information education and communication (IEC) at all level of delivery towards cervical cancer screening.
\end{abstract}

Keywords: acceptability; adult women; cervical cancer screening.

\section{INTRODUCTION}

Cervical cancer is the most common form of cancer among women in developing countries. Hospital based data in Nepal also showed cervical cancer is most commonly occurring cancer among women in Nepal. Pap smear is the very significant screening test for reduction of incidence and mortality from cervical cancer and many developing countries failed to obtained high coverage of target population. ${ }^{1}$ According to a recent study the burden of cancer of cervix is increasing in India. There was 96, 156 cases detected in the year 2011 and the estimated number of cases for the year 2026 is expected to be $148,813 .^{2}$

A cross sectional study in Nigerian women 853 $(56.2 \%)$ were aware of cervical cancer. Though previous cervical cancer screening was low at $9.4 \%$, $79.8 \%(1210)$ accepted to take the test. Cost of the test $(35.2 \%)$ and religious denial $(14.0 \%)$ were the most common reasons given for refusal to take the test. $^{2}$
Cervical cancer is the second commonest cancer in females worldwide and is one of the most important causes of premature death in women of reproductive age. There were 465,000 new case and 226,000 death with $85 \%$ occurring developed countries and $15 \%$ occurring in developing countries.one in 70 women developed cervical cancer between birth and age 79. The objective of this research is to find out the knowledge and acceptability of cervical cancer screening among adult women.

\section{METHODS}

A cross-sectional design was used to find out knowledge and acceptability of cervical cancer screening test among adult women at Bharatpur Hospital, Chitwan from 1st to 15th July 2017. Ethical approval was received from the Nepal Health Research Council (NHRC) and written permission was taken from the authority of Bharatpur Hospital Chitwan. Non-probability

Correspondence: Ms. Bishnu Kumari Shrestha, Bharatpur Nursing College, Bharatpur, Chitwan, Nepal. Email: bishnushrestha2051@yahoo.com. Phone: +977-9845594938. DOI: 10.3126/jcmsn.v15i1.21128. Article received: 2018-09-21. Article accepted: 2019-01-20. 
Shrestha et al. Knowledge and Acceptability of Cervical Cancer Screening among..

purposive sampling technique was used to select 425 gynae patients in OPD. Semi structured questionnaire was develop. Women who were below 30 or above 59 years of age, cervical cancer and hysterectomy patient were excluded. From the total score of knowledge if the level if $<50$ percentile, it means poor level, if level of knowledge lies between 50 to 70 percentile, it is fair level and for $>75$ percentile it is good level. The written informed consent was obtained from each respondent prior to data collection. The information given by respondents was kept confidential by give code number instead of patient name. All data are collected from patient using face to face interview method. Data was analyzed using SPSS version 20. In descriptive statistics frequency table, measure of central tendency, dispersion was used. In inferential statistics chi-square test was used.

\section{RESULTS}

The 425 respondents were surveyed to find out the knowledge and acceptability of cervical cancer screening among adult women. Majority of the respondent's age group were 30-39 years with mean \pm SD age of $40.07 \pm 7.9$ years. Regarding the marital status majority of the respondents are married and one third of the respondents are uneducated, can read and write, majority of them are housewife with Hindu by religion (Table 1).

\begin{tabular}{|c|c|c|}
\hline Variable & $\begin{array}{l}\text { Number of } \\
\text { respondents }\end{array}$ & $\begin{array}{l}\text { Percent- } \\
\text { age }\end{array}$ \\
\hline \multicolumn{3}{|l|}{ Age } \\
\hline $30-39$ & 227 & 53.4 \\
\hline $40-49$ & 124 & 29.2 \\
\hline $50-59$ & 74 & 17.4 \\
\hline \multicolumn{3}{|l|}{ Marital status } \\
\hline Married & 414 & 97.4 \\
\hline Unmarried & 6 & 1.4 \\
\hline Widow & 3 & 0.7 \\
\hline Separate & 2 & 0.5 \\
\hline \multicolumn{3}{|l|}{ Educational status } \\
\hline Uneducated & 127 & 29.9 \\
\hline Can read and write & 116 & 27.3 \\
\hline Primary education & 43 & 10.1 \\
\hline Secondary education & 103 & 24.2 \\
\hline Higher secondary or more & 36 & 8.5 \\
\hline \multicolumn{3}{|l|}{ Occupational status } \\
\hline Agriculture & 106 & 24.9 \\
\hline House manager & 260 & 61.2 \\
\hline Service holder & 20 & 4.7 \\
\hline Business & 37 & 8.7 \\
\hline Others & 2 & 0.5 \\
\hline \multicolumn{3}{|l|}{ Religion } \\
\hline Hindu & 353 & 83.1 \\
\hline Buddhist & 25 & 5.9 \\
\hline Muslim & 19 & 4.5 \\
\hline Christian & 21 & 4.9 \\
\hline Others & 7 & 1.6 \\
\hline
\end{tabular}

Majority 247 (58.1\%) respondents had good knowledge, $96(22.6 \%)$ respondents had fair knowledge and $82(19.3 \%)$ respondent had poor knowledge. Regarding acceptability of cervical cancer screening, majority $282 \quad(66.4 \%)$ respondent accepted. (Table 2)

\begin{tabular}{|c|c|c|}
\hline \multicolumn{3}{|c|}{$\begin{array}{l}\text { Table 2. Knowledge of Cervical Cancer Screening } \\
(n=425)\end{array}$} \\
\hline $\begin{array}{l}\text { Knowledge of cervical cancer } \\
\text { screening }\end{array}$ & Frequency & Percent \\
\hline Poor & 82 & 19.3 \\
\hline Fair & 96 & 22.6 \\
\hline Good & 247 & 58.1 \\
\hline \multicolumn{3}{|c|}{ Acceptability of cervical cancer screening } \\
\hline Accepted & 282 & 66.4 \\
\hline Not accepted & 183 & 33.6 \\
\hline
\end{tabular}

There is significant association between knowledge of cervical cancer screening with educational status $(p=0.04)$, religion $(p=0.01)$. There is no association between knowledge of cervical cancer screening with age $(p=0.08)$, marital status $(\mathrm{p}=0.32)$ occupational status $(\mathrm{p}=0.12)$. (Table 3). There is no association between respondents' level of knowledge and

\begin{tabular}{|c|c|c|c|c|}
\hline \multirow{3}{*}{ Variable } & & & & \\
\hline & \multicolumn{3}{|c|}{ Level of Knowledge } & \multirow{2}{*}{$\begin{array}{l}\text { P- } \\
\text { value }\end{array}$} \\
\hline & Poor & Fair & Good & \\
\hline \multicolumn{5}{|l|}{ Age } \\
\hline $30-39$ & 36 & 61 & 130 & \multirow{3}{*}{$\begin{array}{l}0.08 * \\
*\end{array}$} \\
\hline $40-49$ & 27 & 25 & 72 & \\
\hline $50-59$ & 19 & 10 & 45 & \\
\hline \multicolumn{5}{|l|}{ Marital status } \\
\hline Married & 78 & 94 & 242 & \multirow{4}{*}{$\begin{array}{l}0.32 \\
*\end{array}$} \\
\hline Unmarried & 3 & 0 & 3 & \\
\hline Widow & 1 & 1 & 1 & \\
\hline Separate & 0 & 1 & 1 & \\
\hline \multicolumn{5}{|l|}{ Educational status } \\
\hline Uneducated & 36 & 28 & 63 & \multirow{5}{*}{$\begin{array}{l}0.04 * \\
*\end{array}$} \\
\hline Can read and write & 23 & 27 & 66 & \\
\hline Primary education & 9 & 10 & 24 & \\
\hline Secondary education & 12 & 23 & 68 & \\
\hline Higher secondary or more & 2 & 8 & 26 & \\
\hline \multicolumn{5}{|l|}{ Occupational status } \\
\hline Agriculture & 18 & 29 & 59 & \multirow{5}{*}{$0.12 *$} \\
\hline House manager & 58 & 56 & 146 & \\
\hline Service holder & 2 & 6 & 12 & \\
\hline Business & 4 & 4 & 29 & \\
\hline Others & 0 & 1 & 1 & \\
\hline \multicolumn{5}{|l|}{ Religion } \\
\hline Hindu & 68 & 72 & 213 & \multirow{5}{*}{$\begin{array}{l}0.01 \\
*\end{array}$} \\
\hline Buddhist & 5 & 13 & 7 & \\
\hline Muslim & 1 & 4 & 14 & \\
\hline Christian & 6 & 4 & 11 & \\
\hline Others & 2 & 3 & 2 & \\
\hline
\end{tabular}


acceptability of cervical cancer screening $(\mathrm{p}=0.02)$ (Table 4).

\begin{tabular}{|lllll|}
\hline \multicolumn{5}{|c|}{ Table 4. Association between Respondents' level of } \\
Knowledge and acceptability of cervical caner. \\
\hline Variable & Level of Knowledge & P- \\
Not accepted & Poor & Fair & Good & value \\
Accepted & 37 & 35 & 71 & 0 \\
\hline $\mathrm{c}^{2}$ test is computed for P value & 61 & 176 & \\
\hline
\end{tabular}

\section{DISCUSSION}

This study revealed that the mean \pm SD age of 40.07 \pm 7.9 years. The most common age groups were 30 -39 years. Regarding occupation $(61.2 \%)$ were house wife. In present study regarding information received about cervical cancer, $26.6 \%$ from radio/ $\mathrm{TV}, 12.7 \%$ family member,

$9.9 \%$ from health worker. The findings of this study is supported by another the study shows that information about cervical cancer mostly from either foreign media $28.5 \%(118 / 414) .{ }^{4}$ This study shows that regarding sign and symptom of cervical cancer, $71.3 \%$ agreed foul smelling vaginal discharge, $60.7 \%$ were post menopausal bleeding. The findings of this study is supported by the study shows post-menopausal bleeding (84\%), and offensive vaginal discharge $(83 \%){ }^{5}$ This study revealed knowledge of cervical cancer $(58.1 \%)$ respondents had good knowledge; mean knowledge on cervical cancer was $(67 \%)$. Similar with other study conducted in Udaipur district which shows that $(63.3 \%)$ had good knowledge about cervical cancer. ${ }^{6}$

This study shows that there is statistically significant association between respondents knowledge of cervical cancer screening and educational status $(\mathrm{p}=0.04)$, religion $(\mathrm{p}=0.01)$. Another similar study result shows that awareness was positively associated with higher levels of education, socioeconomic status and occupational status $(\mathrm{p}<0.05)^{7}$

This study showed that $(56.2 \%)$ had never practice for screening. The study finding was consistent with the other studies done in Nepal which shows the uptake of screening to be from ( $7 \%$ to $15 \%)$. The findings shows that despite the introduction of cervical cancer screening in the national program of Nepal the screening practice in Nepalese women

\section{REFERENCES}

1. Sherpa, A.T., Karki, B.S., Franceschil, S.\& Clifford, G. Population based study of cervical cancer,screening in Bharatpur Nepal. 2015., has not increased. Regarding frequency of cervical screening, (26.1\%) of the respondents screening had done only one time. The study findings were contradiction with those of other countries like India, Bhutan and Nigeria. The findings of India Bhopal show only (9\%), that had screened for cervical cancer at least once, in Bhutan $(6 \%)$ and Nigeria women were $(13 \%){ }^{8}$ The findings of this study showed that, $(82.8 \%)$ respondent said that negligence, $(81.9 \%)$ )respondents said that fear of painful procedure, $(77.9 \%)$ respondents said that lack of money, $(75.5 \%)$ said that fear of diagnosed cancer $(54.4 \%)$ respondents said that stigma is a main reason for not necessary to pap smear test. The findings was contradiction with other study result shows that, the most common reason for not undergoing pap smear testing was neglect $(50 \%)$ followed by lack of financial resources $(13.6 \%)$, fear of discovering a serious disease $(13.6 \%)$ and deeming it unimportant $(13.6 \%)^{6}$

This study findings shows that (39.3\%) respondents had good knowledge, on pap smear test similar study conducted by Shrestha shows that (47\%) of women had adequate knowledge of Pap smear test. This study revealed that fair knowledge on pap smear test $(22.6 \%)$, in contrast study by Ahmed, Sabitu \& Ahmed (2013) showed that there was a fair knowledge (43.5\%). ${ }^{9}$

This study findings revealed that, regarding acceptability of cervical cancer screening, majority (66.4\%) respondent accepted cervical screening, similar findings were reported by Ezechi., Okafor, Ostergren, \& Pettersson (2013) shows that (79.8\%) respondents accepted to take cervical cancer.

\section{CONCLUSIONS}

Education can play a crucial role in the screening of cervical cancer. Health care provider should provide the information education and communication (IEC) at all level of delivery towards cervical cancer screening to the patients and families. Awareness campaign can help increased acceptability in practice of the various cervical cancer screening test in ordered to detect high risk and early stage of cervical cancer.

orginal article volume1, isssue4.retrived on 23 march from www.nepjol.info $>$ article $>$ download.

2. Ezechi, O.C.,Okafor, C.V., Ostergren, P.O.\& Pettersson, K.O. Willingness and 
Shrestha et al. Knowledge and Acceptability of Cervical Cancer Screening among..

acceptability of cervical cancer screening among HIV positive Nigerian. women. published online 2013., Jan 17. doi:10.1186/1471-2458-13-46.

3. Global Burden of Disease Cancer Collaboration .The Global Burden of Disease 2013.JAMA oncology,2015, Dol:10.1001/ jamaoncol.2015.0735

4. Assoumou, S.Z., Barthelemy, M., Mbiguino, A.N., Mouallif, M., Khattabi, A.\& Ennaj, M. Awareness and knowledge regarding of cervical cancer, Pap smear screening and human papilloma virus infection in Gabonese women BMC Women's Health 201515:37 DOI: $10.1186 / \mathrm{s} 12905-015-0193-2$

5. Mwaka, A.D., Orach, C.G. \& Ronald, M. Awareness of cervical cancer risk factor symptom cross sectional community survey in post conflict Northen Ugenda. International journal of public participation in health care and health policy, 2015., retrieved from https:// wwwncbi.nlm.nih.gov>articles

6. Ranabhat, S., Tiwari, M., Dhungana, G.\& Shrestha, R. Pap smear coverage and effect of knowledge and attitude regarding cervical cancer on utilization of the test by women in Udhayapur district of Nepal. Journal of Chitwan Medical College 2014; 4 (10): 31-35 Available online at: www.jcmc.cmc.edu.np

7. Mani, G., Annadurai, K.\& Danasekaran, R, . Awareness Regarding Cervical Cancer and Preventive Practices Among Rural Married Women of Kanchee puram District, Tamil Nadu. Journal of Comprehensive Health, January 2014| Volume 2 | Issue 1

8. Thippeveeranna,C., Sadhana, M.S., Ranjit, S.L. \& Singh, N.N. Knowledge, Attitude and Practice of the Pap Smear as a Screening Procedure Among Nurses in a Tertiary Hospital in North Eastern India. DOI:http://dx.doi.org/ 10.7314/ APJCP. 2013.14.2.849

9. Ahmed, S. A., Sabitu, K., Idris,S. H.,\& Ahmed.,R. Knowledge, attitude and practice of cervical cancer screening among market women in Zaria, Nigeria.Niger Med J. 2013 Sep-Oct; $54 \quad$ (5): $316-$ 319.doi:10.4103/0300-1652.122337.Retrived on 28 marchfrom htts:/www.ncbi.nlm.nih.gov/ pmc/articles/PMC3883231/

Citation: Shrestha BK, Sapkota DK, Sapkota M. Knowledge and Acceptability of Cervical Cancer Screening among Adult Women Visiting in Gynecological OPD. JCMS Nepal. 2019;15(1):67-70. 